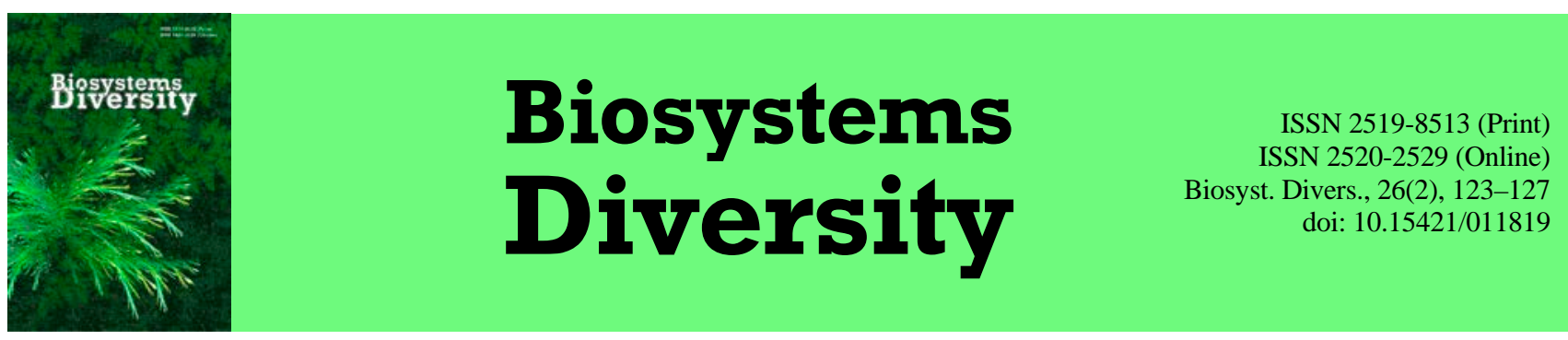

\title{
Features of the daily dynamics of trophic activity of various types of blood-sucking mosquitoes (Diptera, Culicidae) in the south of Tyumen region
}

\author{
T. A. Khlyzova \\ Tobolsk Complex Scientific Station UD RAS, Tobolsk, Russia
}

Article info

Received 03.03.2018

Received in revised form 19.04.2018

Accepted 21.04.2018

Tobolsk Complex Scientific Station UD RAS,

acad. Y. Osipova st., 15 ,

Tobolsk, 626152, Russia.

Tel.: +7-909-735-84-88

E-mail:

labdezinsekcii@mail.ru
Khlyzova, T. A. (2018). Features of the daily dynamics of trophic activity of various types of blood-sucking mosquitoes (Diptera, Culicidae) in the south of Tyumen region. Biosystems Diversity, 26(2), 123-127. doi:10.15421/011819

We conducted research on the determination of the daily activity of blood-sucking mosquitoes of the family Culicidae in 2005-2015 in the south of Tyumen region in three climatic zones (subzones): the subzone of the southern taiga (Nizhnetavdinsky district), the subzone of aspen-birch forests (Tyumen and Yalutorovsky districts) and in the forest-steppe zone (Isetsky district). In each of the three subzones, counts were conducted twice for the summer season - in June and July. A high number of blood-sucking mosquitoes in the south of the Tyumen region have 24-hour activity. The maximum number in all natural and climatic zones of the region is observed at 23 hours. The daily rhythm of activity of certain species of mosquitoes depends on their abundance in the summer season and on their ecological characteristics. The optimal meteorological conditions under which an active flight of mosquitoes are observed: air temperature $12.6-26.0^{\circ} \mathrm{C}$, relative humidity of air - 54-100\% and illuminance - 0-8600 lux. In studying the circadian rhythm, 29 mosquito species of the family Culicidae, belonging to 6 genera: Anopheles, Culiseta, Coquillettidia, Aedes, Ochlerotatus and Culex, were recorded. In the subzone of the southern taiga, we recorded a flight of 25 species, in the subzone of small-leaved aspen-birch forests 20 , and in the forest-steppe zone - 24. The peak of species diversity in all three subzones coincided with the maximum number. All registered species in terms of temperature preferences (thermophilicity) can be conditionally divided into two groups. The first group ( 10 species) are species that actively attack at a temperature $10-20^{\circ} \mathrm{C}$. The second group ( 19 species) are species that actively attack at an air temperature $10-30^{\circ} \mathrm{C}$.

Keywords: mosquitoes; species diversity; daily rhythm of activity; air temperature

\section{Introduction}

Over the day, the activity of Culicidae changes due to the constant impact of periodically changing environmental factors. According to the literature data, daily rhythm of Culicidae activity significantly depends on the number of these insects over the year of study and meteorological conditions during the period of the study. The greatest impact on the activity of mosquitoes, according to a number of researchers, is caused by the temperature and relative humidity, illuminance and wind (Monchadskiy, 1950, 1958; Polyakova \& Patrusheva, 1974; Chernyshev, 1981). Depending on the fluctuations of these meteorological characteristics over the day, the activity of mosquitoes significantly varies. The activity of mosquitoes increases in the evening - before sundown and in the morning - before sunrise. Quick transition of daylight to twilight and night darkness to sunrise is a stimulus for female mosquitoes. Over the day, the activity of mosquitoes is inhibited by high temperature and bright light, and in the night - by decrease in the temperature and the dark. The activity of mosquitoes is to a large extent affected by heavy rains and dew. Insignificant rains have no impact on the most species of mosquitoes. The optimum humidity for mosquitoes ranges within 50-99\% (Anufriyeva, 1971; Red'kina, 2008). Because in various geological areas and natural-climatic zones, different meteorological conditions are formed, the daily local rhythm of mosquito activity has a number of peculiarities.

\section{Materials and methods}

We conducted our study on the determination of daily activity of Culicidae in 2005-2015 in the south of Tyumen oblast and three natural-climatic zones (subzones): the subzone of northern taiga (Nizhne- tavdinsky District), the subzone of aspen-birch forests (Tyumen \& Yalutorovsky Districts) and the forest-steppe zone (Isetsky District). In each of the three subzones, counts were made twice over the summer season - in June and July.

The count of attacking mosquitoes was conducted using a butterfly net with removable mesh (Rasnitsyn \& Kosovskikh, 1979) in 5 replications. The trajectory of every sweep of the butterfly net resembled the figure "eight" and consisted of two moves: at the level of the head and level of the knees. One replication included 10 such sweeps. Each replication of the count was made at a new spot, moving 20-30 steps along a fixed route in a selected plot after a change of net by, i.e. along a so called transect. Because during the day, mosquitoes prefer forest areas of pastures, an area of collecting usually was a forest edge and forest $30 \mathrm{~m}$ away from the edge. At the same time, we used the schemes suggested by Lubishevy (1958) and Pesenko (1982). Unlike the method of quantitative count along a transect, described by Petrozhytska et al. (2002), we made our counts only in particular areas, without repeated visits, and not constantly along a route in a there and back manner. The interval between the counts was two hours. At the same time, we recorded the temperature and relative humidity, wind speed, the amount of precipitation.

For identification of the species composition of mosquito imagoes, we used special identification tables of Kukharchuk (1980) and Gornostayeva \& Danilov (1999), classifying Ochlerotatus subgenus as a genus (Gornostayeva, 2009).

\section{Results}

The studies conducted earlier determined that in the conditions of the subzone of the southern taiga, under the canopy of the forest, during the mass flight in the June-July - mosquitoes struck humans 
throughout the day (Khlyzova \& Pavlova, 2006; Khlyzova \& Latkin, 2015). In June, the highest number of mosquitoes was observed at $23 \mathrm{~h}$ (i.e. $11 \mathrm{pm}$ ) and from $3 \mathrm{~h}$ to $7 \mathrm{~h}$ (i.e. $3 \mathrm{am}-7 \mathrm{am}$ ). In late July, two maxima were observed over the $24 \mathrm{~h}$ activity: $21-23 \mathrm{~h}$ and 5-7 h. On open ground, the number of mosquitoes was much lower compared to the forest, and the daily dynamic of the flight in June was characterized by prolonged activity in the night (from 23 to $5 \mathrm{~h}$ ) and the absence of strikes over the day.

During the study on the daily rhythm of mosquitoes activity in the conditions of the subzone of the southern taiga, we recorded flight of 25 species (Table 1). The maximum species diversity was recorded at $23 \mathrm{~h}$. At that time, there were observed strikes by 20 species of mosquitoes: the complex Anopheles maculipennis Mg., Culiseta alaskaensis Ludl., Coquillettidia richiardii Fic., Aedes cinereus Mg., Ae. rossicus D. G. M., Ae. vexans Mg., Ochlerotatus caspius Pall., O. cantans Mg., O. riparius D. K., O. mercurator Dyar., O. behningi Mart., O. excrucians Walk., O. euedes H. D. K., O. cyprius Ludl., O. flavescens Mull., O. communis Deg., O. punctor Kirby, O. diantaeus H. D. K., O. intrudens Dyar., Culex modestus Fic. For the rest of the time, the number of attacking species ranged from 12 to 19 . We observed the minimum species diversity of mosquitoes at $15 \mathrm{~h}$, when active strikes were made by females of 12 species of mosquitoes. $24 \mathrm{~h}$ activity was manifested by 10 species: Ae. cinereus, Ae. vexans, O. cantans, O. riparius, O. excrucians, O. euedes, O. cyprius, $O$. communis, $O$. punctor, $O$. diantaeus. The shortest period of activi- ty was observed among $C$. richiardii and $C$. modestus, these species were found caught only at $23 \mathrm{~h}$.

In the subzone of small-leaved aspen-birch forests of Tyumen oblast in June, the peak activity of strikes of mosquitoes in the forests was recorded in the period $23-5 \mathrm{~h}$, and at $23 \mathrm{~h}$ and $7-11 \mathrm{~h}$ on open ground. The peaks of the number of mosquitoes were observed in June under the forest canopy at 23 and $5 \mathrm{~h}$. On open ground, the maximum activities of mosquito strikes were recorded at hour $23 \mathrm{~h}$ and $7 \mathrm{~h}$ as under the forest canopy (Khlyzova \& Latkin, 2015).

In July, the period of the highest mosquito activity under the forest canopy and on open ground lasted from $21 \mathrm{~h}$ to $5 \mathrm{~h}$. The peaks of activity were recorded at $21 \mathrm{~h}$ and $5 \mathrm{~h}$, and at $1 \mathrm{~h}$ on open ground.

During recording the $24 \mathrm{~h}$ rhythm of mosquitoes' activity, we observed active strikes at humans by females of 20 species of mosquitoes (Table 2). The period of activity of most species recorded during the counts (17-19 species) lasted from $21 \mathrm{~h}$ to $3 \mathrm{~h}$, i.e. in the period of the optimum meteorological conditions (temperature and relative humidity and illuminance). The peak of species diversity was recorded at $23 \mathrm{~h}$, when the highest number of striking mosquitoes during the $24 \mathrm{~h}$ period was observed. At that time, we recorded strikes of females of 19 species: Culiseta morsitans Theob., Ae. cinereus, Ae. rossicus, Ae. vexans, O. caspius, O. cantans, O. riparius, O. mercurator, O. behningi, O. excrucians, O. euedes, O. cyprius, O. flavescens, O. communis, O. punctor, O. diantaeus, O. intrudens, O. cataphylla Dyar. and C. modestus.

Table 1

Twenty-four-hour activity of different species of mosquitoes in the conditions of the southern taiga

\begin{tabular}{|c|c|c|c|c|c|c|c|c|c|c|c|c|c|}
\hline \multirow{2}{*}{ Species } & \multicolumn{12}{|c|}{ The number of individuals caught } & \multirow{2}{*}{ Total } \\
\hline & $07 \mathrm{~h}$ & $09 \mathrm{~h}$ & $11 \mathrm{~h}$ & $13 \mathrm{~h}$ & $15 \mathrm{~h}$ & $17 \mathrm{~h}$ & $19 \mathrm{~h}$ & $21 \mathrm{~h}$ & $23 \mathrm{~h}$ & $01 \mathrm{~h}$ & $03 \mathrm{~h}$ & $05 \mathrm{~h}$ & \\
\hline Aedes cinereus Mg. & 115 & 111 & 36 & 15 & 59 & 72 & 52 & 215 & 321 & 47 & 26 & 64 & 1133 \\
\hline Ae. vexans Mg. & 36 & 22 & 36 & 4 & 6 & 18 & 20 & 54 & 170 & 35 & 36 & 31 & 468 \\
\hline Ochlerotatus cantans Mg. & 423 & 302 & 215 & 126 & 66 & 127 & 111 & 379 & 590 & 133 & 93 & 354 & 2919 \\
\hline O. riparius D. K. & 59 & 134 & 70 & 16 & 16 & 5 & 26 & 34 & 60 & 40 & 62 & 85 & 607 \\
\hline O. excrucians Walk. & 249 & 203 & 123 & 72 & 66 & 72 & 78 & 190 & 390 & 135 & 98 & 337 & 2013 \\
\hline O. euedes H. D. K. & 40 & 91 & 40 & 10 & 4 & 7 & 7 & 25 & 68 & 27 & 26 & 55 & 400 \\
\hline O. cyprius Ludl. & 27 & 20 & 4 & 3 & 5 & 9 & 10 & 16 & 9 & 18 & 7 & 42 & 170 \\
\hline O. communis Deg. & 61 & 26 & 7 & 6 & 7 & 14 & 4 & 55 & 82 & 15 & 3 & 57 & 337 \\
\hline O. punctor Kirby & 199 & 181 & 76 & 27 & 16 & 24 & 19 & 98 & 353 & 177 & 144 & 279 & 1593 \\
\hline O. diantaeus H. D. K. & 139 & 45 & 16 & 6 & 17 & 27 & 31 & 44 & 124 & 24 & 19 & 52 & 544 \\
\hline Ae. rossicus D. G. M. & 8 & - & 1 & - & - & - & - & 9 & 7 & 4 & - & 9 & 38 \\
\hline O. caspius Pall. & 3 & 7 & - & - & - & 14 & - & 13 & 50 & 1 & 11 & 2 & 101 \\
\hline O. mercurator Dyar. & 3 & 15 & - & - & 4 & 8 & 5 & 7 & 5 & 6 & 2 & - & 55 \\
\hline O. intrudens Dyar. & 80 & 5 & 20 & 8 & - & - & - & - & 10 & - & 3 & - & 126 \\
\hline Culiseta longiareolata Macq. & 8 & - & - & - & - & - & - & - & - & - & - & - & 8 \\
\hline O. dorsalis Mg. & - & 1 & 1 & 1 & - & 7 & 6 & 9 & - & 1 & 1 & - & 27 \\
\hline O. leucomelas Mg. & - & 3 & - & - & - & - & - & - & - & - & - & - & 3 \\
\hline O. cataphylla Dyar. & - & - & 10 & 1 & - & - & - & - & - & - & - & - & 11 \\
\hline O. flavescens Mull. & - & - & - & - & 2 & - & 3 & 6 & 24 & 5 & - & 3 & 43 \\
\hline O. behningi Mart. & - & - & - & - & - & - & - & 3 & 4 & 2 & 3 & - & 12 \\
\hline Комплекс Anopheles maculipennis Mg. & - & - & - & - & - & - & - & - & 22 & 7 & 5 & - & 34 \\
\hline Cs. ochroptera Peus & - & - & - & - & - & - & - & - & - & 3 & 3 & - & 6 \\
\hline Cs. alaskaensis Ludl. & - & - & - & - & - & - & - & - & 7 & 5 & 2 & - & 14 \\
\hline Coquillettidia richiardii Fic. & - & - & - & - & - & - & - & - & 16 & - & - & - & 16 \\
\hline Culex modestus Fic. & - & - & - & - & - & - & - & - & 11 & - & - & - & 11 \\
\hline Total: individuals & 1450 & 1166 & 655 & 295 & 268 & 404 & 372 & 1157 & 2323 & 685 & 544 & 1370 & 10689 \\
\hline of species & 15 & 15 & 14 & 13 & 12 & 13 & 13 & 16 & 20 & 19 & 18 & 13 & 25 \\
\hline
\end{tabular}

In the daytime, the number of flying species decreased to 8-16. Twenty-four-hour activity was observed among 5 species of mosquitoes: Ae. cinereus, Ae. rossicus, Ae. vexans, O. cantans and O. excrucians. The shortest period of flight was recorded for two species: C. morsitans, strikes of females of this species on humans were recorded only at $23 \mathrm{~h}$, and Ochlerotatus sticticus Mg., single females of this species were caught at $3 \mathrm{~h}$.

In the conditions of forest-steppe zone of Tyumen oblast, we determined that in June under the forest canopy, mosquitoes struck humans throughout the $24 \mathrm{~h}$ period. On open ground, mosquitoes were not active in the daytime, their strikes was not recorded from $9 \mathrm{~h}$ to $17 \mathrm{~h}$ and at $21 \mathrm{~h}$. In the twenty-four-hour rhythm of activity in both habitats, we observed two peaks at $23 \mathrm{~h}$ and $05 \mathrm{~h}$ (Khlyzova \& Latkin, 2015). In July, under the forest canopy, mosquito strikes were not observed only at $15 \mathrm{~h}$ and $19 \mathrm{~h}$, and on open ground, they actively struck only at $23 \mathrm{~h}$ and $5 \mathrm{~h}$.

During the study of the twenty-four-hour rhythm of mosquito activity in the forest-steppe zone of Tyumen oblast, we recorded strikes of 24 species of mosquitoes (Table 3). Active flight of the highest number of species (14-16 species) was observed in the period from $23 \mathrm{~h}$ to $1 \mathrm{~h}$, i.e. during the maximum $24 \mathrm{~h}$ activity. Maximum species diversity was observed at $23 \mathrm{~h}-$ at that time, we recorded strikes on humans by $C$. richiardii, Ae. cinereus, Ae. rossicus, Ae. vexans, $O$. caspius, $O$. dorsalis Mg., O. behningi, O. cantans, O. riparius, O. excrucians, O. euedes, O. cyprius, O. punctor, O. diantaeus, $O$. intrudens and $C$. pipiens. In the daytime, only individuals of the most common species were observed. The minimum species diversity was recorded at $11 \mathrm{~h}$ (i.e. $11 \mathrm{am}$ ), when humans were struck by 
single individuals of $O$. riparius, $O$. punctor and $O$. diantaeus, and at $13 \mathrm{~h}$, when the counts included $O$. cantans, O. diantaeus and Ae. rossicus. The species which in the southern taiga and small-leaved aspen-birch forests were characterized by twenty-four-hour activity, due to their low number, struck mostly in the evening and morning hours in the forest-steppe zone.

During conducting all the recording of the 24-h rhythm of mosquito activity, the air temperature fluctuated within $10-30{ }^{\circ} \mathrm{C}$. We recorded no temperature below 10 and above $30^{\circ} \mathrm{C}$. The analysis of meteorological conditions over the 24-h recording in 2005-2015 indicated active strikes of mosquito females at the temperature of 12.6-30.0 ${ }^{\circ} \mathrm{C}$, relative humidity of $33-100 \%$ and $0-37,000$ lux illuminance. During the highest activity of mosquitoes, the air temperature equaled $12.6-26.0{ }^{\circ} \mathrm{C}$, relative humidity - 54-100\%, illuminance 0-8,600 lux. All 29 species recorded over the study could be conventionally divided into two groups in relation to their preferences (ther- mophilicity): the species which actively struck at the temperature 10 $20^{\circ} \mathrm{C}$, and species which actively struck at the air temperature 10 $30{ }^{\circ} \mathrm{C}$ (Table 4). The first group included 10 species, one of them (C. ochroptera) had a clearly manifested peak of activity at the temperature range of $10-15^{\circ} \mathrm{C}, 6$ species (A. maculipennis complex, C. alaskaensis, C. morsitans, C. richiardii, C. modestus and C. pipiens) struck most actively at $15-20{ }^{\circ} \mathrm{C}$, three species (O. sticticus, $O$. pionips and $O$. behningi) had no clearly manifested peak of activity and practically equally struck both at $10-15$ and at $15-20^{\circ} \mathrm{C}$.

The second group is represented by 19 species. Among them, 14 species had their peak strike activity at the temperature of 15$20^{\circ} \mathrm{C}$, and two species (O. leucomelas and $C$. pipiens) were observed to strike only at this temperature, one species (O. dorsalis) at the air temperature of $20-25^{\circ} \mathrm{C}$. O. punctor was the most active at 10 $20^{\circ} \mathrm{C}$, and $O$. cantans - at $15-25^{\circ} \mathrm{C}$. Therefore, the highest number of mosquitoes was caught at the air temperature of $15-20^{\circ} \mathrm{C}$.

Table 2

Twenty-four-hour activity of different species of mosquitoes in the conditions of the subzone of small-leaved aspen-birch forests

\begin{tabular}{|c|c|c|c|c|c|c|c|c|c|c|c|c|c|}
\hline \multirow{2}{*}{ Species } & \multicolumn{12}{|c|}{ Number of individuals caught } & \multirow{2}{*}{ Total } \\
\hline & $07 \mathrm{~h}$ & $09 \mathrm{~h}$ & $11 \mathrm{~h}$ & $13 \mathrm{~h}$ & $15 \mathrm{~h}$ & $17 \mathrm{~h}$ & $19 \mathrm{~h}$ & $21 \mathrm{~h}$ & $23 \mathrm{~h}$ & $01 \mathrm{~h}$ & $03 \mathrm{~h}$ & $05 \mathrm{~h}$ & \\
\hline Aedes cinereus Mg. & 211 & 61 & 51 & 27 & 31 & 44 & 36 & 272 & 441 & 170 & 140 & 102 & 1586 \\
\hline Ae. rossicus D. G. M. & 4 & 14 & 14 & 6 & 7 & 4 & 7 & 51 & 95 & 41 & 43 & 25 & 311 \\
\hline Ae. vexans Mg. & 16 & 24 & 19 & 10 & 2 & 14 & 13 & 21 & 52 & 37 & 25 & 49 & 282 \\
\hline Ochlerotatus cantans Mg. & 98 & 84 & 67 & 52 & 45 & 17 & 21 & 98 & 378 & 109 & 138 & 206 & 1313 \\
\hline O. excrucians Walk. & 51 & 20 & 26 & 24 & 47 & 7 & 12 & 46 & 162 & 83 & 101 & 130 & 709 \\
\hline O. caspius Pall. & 1 & 6 & 10 & 8 & 12 & 6 & 5 & 6 & 5 & 2 & - & - & 61 \\
\hline O. riparius D. K. & 7 & 7 & 1 & - & 1 & - & 3 & 4 & 22 & 4 & 18 & 8 & 75 \\
\hline O. mercurator Dyar. & 7 & 7 & 7 & - & - & - & - & 7 & 37 & 4 & 2 & 4 & 75 \\
\hline O. euedes H. D. K. & 7 & 8 & 5 & 5 & 2 & - & 2 & 7 & 36 & 38 & 25 & 36 & 171 \\
\hline O. cyprius Ludl. & 3 & - & - & 7 & 4 & 2 & 3 & 16 & 52 & 2 & 7 & 14 & 110 \\
\hline O. punctor Kirby & 11 & 19 & 23 & 6 & - & 3 & 10 & 29 & 45 & 14 & 28 & 18 & 206 \\
\hline O. communis Deg & 2 & - & - & - & - & - & - & 14 & 8 & 8 & 4 & 8 & 44 \\
\hline O. diantaeus H. D. K. & 3 & 1 & - & 8 & - & - & - & 5 & 17 & 8 & 11 & 18 & 71 \\
\hline O. intrudens Dyar. & 6 & - & - & - & - & - & - & - & 7 & 13 & 10 & 13 & 49 \\
\hline O. cataphylla Dyar. & 2 & - & - & 3 & - & - & - & 1 & 1 & - & - & 8 & 15 \\
\hline O. behningi Mart. & 1 & - & - & - & - & - & - & - & 7 & 5 & 1 & - & 14 \\
\hline O. flavescens Mull. & - & 8 & - & 3 & 2 & - & 5 & 9 & 77 & 22 & 27 & 4 & 157 \\
\hline Culiseta morsitans Theob. & - & - & - & - & - & - & - & - & 8 & - & - & - & 8 \\
\hline O. sticticus Mg. & - & - & - & - & - & - & - & - & - & - & 2 & - & 2 \\
\hline Culex modestus Fic. & - & - & - & - & - & - & - & - & 6 & 4 & 2 & - & 12 \\
\hline Total: individuals & 430 & 259 & 223 & 159 & 153 & 97 & 117 & 586 & 1451 & 564 & 584 & 643 & 5271 \\
\hline of species & 16 & 12 & 10 & 12 & 10 & 8 & 11 & 15 & 19 & 17 & 17 & 15 & 20 \\
\hline
\end{tabular}

Table 3

Twenty-four-hour activity of different species of mosquitoes in the conditions of forest-steppe zone

\begin{tabular}{|c|c|c|c|c|c|c|c|c|c|c|c|c|c|}
\hline \multirow{2}{*}{ Species } & \multicolumn{12}{|c|}{ Number of individuals caught } & \multirow{2}{*}{ Total } \\
\hline & $07 \mathrm{~h}$ & $09 \mathrm{~h}$ & $11 \mathrm{~h}$ & $13 \mathrm{~h}$ & $15 \mathrm{~h}$ & $17 \mathrm{~h}$ & $19 \mathrm{~h}$ & $21 \mathrm{~h}$ & $23 \mathrm{~h}$ & $01 \mathrm{~h}$ & $03 \mathrm{~h}$ & $05 \mathrm{~h}$ & \\
\hline Coquillettidia richiardii Fic. & 4 & - & - & - & - & - & - & - & 9 & 1 & - & 10 & 24 \\
\hline Ochlerotatus cantans Mg. & 4 & 6 & - & 2 & 5 & 4 & - & 7 & 22 & 4 & 4 & 11 & 69 \\
\hline O. riparius D. K. & 2 & 2 & 1 & - & - & - & - & - & 6 & 1 & - & 5 & 17 \\
\hline O. excrucians Walk. & 6 & 2 & - & - & 2 & 4 & 3 & 5 & 5 & 5 & 8 & 10 & 50 \\
\hline O. punctor Kirby & 2 & 8 & 1 & - & 7 & 4 & - & 2 & 28 & 8 & 21 & 50 & 131 \\
\hline O. diantaeus H. D. K. & 3 & 4 & 1 & 1 & - & 2 & 4 & 6 & 2 & - & 12 & 24 & 59 \\
\hline Aedes cinereus Mg. & 4 & - & - & - & - & - & - & 6 & 13 & 4 & - & 2 & 29 \\
\hline Ae. rossicus D. G. M. & 2 & - & - & 1 & - & - & - & 1 & 4 & 1 & - & - & 9 \\
\hline O. intrudens Dyar. & - & 2 & - & - & - & - & 3 & - & 2 & - & - & - & 7 \\
\hline O. euedes H. D. K. & - & - & - & - & 2 & 2 & 3 & 2 & 9 & 3 & 2 & 12 & 35 \\
\hline O. flavescens Mull. & - & - & - & - & - & - & 3 & - & - & 1 & - & - & 4 \\
\hline O. cataphylla Dyar. & - & - & - & - & - & - & 3 & - & - & - & 1 & - & 4 \\
\hline O. caspius Pall. & - & - & - & - & - & - & - & 1 & 6 & 1 & - & 5 & 13 \\
\hline O. communis Deg. & - & - & - & - & - & - & - & 1 & - & - & - & 2 & 3 \\
\hline Ae. vexans Mg. & - & - & - & - & - & - & - & 2 & 18 & 4 & - & 9 & 33 \\
\hline O. dorsalis Mg. & - & - & - & - & - & - & - & - & 4 & - & - & - & 4 \\
\hline O. behningi Mart. & - & - & - & - & - & - & - & - & 4 & 1 & 1 & 10 & 16 \\
\hline O. cyprius Ludl. & - & - & - & - & - & - & - & - & 2 & - & - & - & 2 \\
\hline Culex pipiens L. & - & - & - & - & - & - & - & - & 2 & - & - & - & 2 \\
\hline O. mercurator Dyar. & - & - & - & - & - & - & - & - & - & 1 & - & - & 1 \\
\hline O. sticticus Mg. & - & - & - & - & - & - & - & - & - & 1 & - & - & 1 \\
\hline Culiseta alaskaensis Ludl. & - & - & - & - & - & - & - & - & - & - & 1 & - & 1 \\
\hline Cs. morsitans Theob. & - & - & - & - & - & - & - & - & - & - & 1 & - & 1 \\
\hline O. pionips Dyar. & - & - & - & - & - & - & - & - & - & - & 2 & 2 & 4 \\
\hline \multirow{2}{*}{ Total: individuals of species } & 27 & 24 & 3 & 4 & 16 & 16 & 19 & 33 & 136 & 36 & 53 & 152 & 519 \\
\hline & 8 & 6 & 3 & 3 & 4 & 5 & 6 & 10 & 16 & 14 & 10 & 13 & 24 \\
\hline
\end{tabular}


Table 4

The correspondence of the blood-sucking mosquitoes to different air temperatures

\begin{tabular}{|c|c|c|c|c|c|c|}
\hline \multirow[b]{2}{*}{ № } & \multirow[b]{2}{*}{ Species } & \multirow{2}{*}{$\begin{array}{c}\text { Total of } \\
\text { mosquitoes } \\
\text { caught }\end{array}$} & \multicolumn{4}{|c|}{ Out of them, at the temperature of } \\
\hline & & & $\begin{array}{c}10-15 \\
{ }^{\circ} \mathrm{C}\end{array}$ & $\begin{array}{c}15-20 \\
{ }^{\circ} \mathrm{C}\end{array}$ & $\begin{array}{c}20-25 \\
{ }^{\circ} \mathrm{C}\end{array}$ & $\begin{array}{c}25-30 \\
{ }^{\circ} \mathrm{C}\end{array}$ \\
\hline 1 & $\begin{array}{l}\text { Complex Anopheles } \\
\text { maculipennis Mg. }\end{array}$ & 34 & 9 & 25 & - & - \\
\hline 2 & Culiseta ochroptera Peus & 6 & 5 & 1 & - & - \\
\hline 3 & Cs. alaskaensis Ludl. & 15 & 6 & 9 & - & - \\
\hline 4 & Cs. morsitans Theob. & 9 & 1 & 8 & - & - \\
\hline 5 & Coquillettidia richiardii Fic. & 40 & 8 & 32 & - & - \\
\hline 6 & Ochlerotatus sticticus Mg. & 3 & 2 & 1 & - & - \\
\hline 7 & O. pionips Dyar. & 4 & 3 & 1 & - & - \\
\hline 8 & Culex modestus Fic. & 23 & 6 & 17 & - & - \\
\hline 9 & O. behningi Mart. & 42 & 19 & 23 & - & - \\
\hline 10 & Cs. longiareolata Macq. & 8 & 6 & 2 & - & - \\
\hline 11 & O. leucomelas Mg. & 3 & - & 3 & - & - \\
\hline 12 & Cx. pipiens L. & 2 & - & 2 & - & - \\
\hline 13 & Aedes cinereus Mg. & 2748 & 313 & 1557 & 703 & 175 \\
\hline 14 & Ae. rossicus D. G. M. & 358 & 88 & 159 & 60 & 51 \\
\hline 15 & xans Mg. & 783 & 182 & 359 & 155 & 87 \\
\hline 16 & O. caspius Pall. & 175 & 21 & 65 & 50 & 39 \\
\hline 17 & O. dorsalis Mg. & 31 & 3 & 5 & 23 & - \\
\hline 18 & O. cantans Mg. & 4301 & 981 & 1697 & 1125 & 498 \\
\hline 19 & O. riparius D. K. & 699 & 178 & 212 & 155 & 154 \\
\hline 20 & O. mercurator Dyar. & 131 & 17 & 63 & 40 & 11 \\
\hline 21 & O. excrucians Walk. & 2772 & 718 & 929 & 601 & 524 \\
\hline 22 & O. euedes H. D. K. & 606 & 175 & 204 & 126 & 101 \\
\hline 23 & O. flavescens Mull. & 204 & 57 & 101 & 22 & 24 \\
\hline 24 & O. cyprius Ludl. & 282 & 70 & 103 & 61 & 48 \\
\hline 25 & O. communis Deg. & 384 & 88 & 172 & 81 & 43 \\
\hline 26 & O. punctor Kirby & 1930 & 576 & 593 & 393 & 368 \\
\hline 27 & O. diantaeus H. D. K. & 674 & 92 & 335 & 181 & 66 \\
\hline 28 & O. intrudens Dyar. & 182 & 31 & 116 & 29 & 6 \\
\hline 29 & O. cataphylla Dyar. & 30 & 6 & 9 & 11 & 4 \\
\hline & Total: of species & 29 & 27 & 29 & 17 & 16 \\
\hline & individuals & 16479 & 3661 & 6803 & 3816 & 2199 \\
\hline
\end{tabular}

\section{Discussion}

Practically all available domestic literature characterizes the quantitative aspect of the 24-h rhythm of mosquitoes, i.e. reflects the fluctuations of their number. At the same time, the materials do not reveal the changes in the species composition of striking females over the 24-h period. The foreign literature contains some fragmented data on the ecological preferences of certain species of mosquitoes (Forattini \& de Castro Gomes, 1988; Charlwood, 1996; Voorham, 2002; Montarsi et al., 2015; Kim et al., 2016). The study we conducted on 24-h rhythm of activity of blood-sucking mosquitoes in the conditions of the southern Tyumen oblast allowed us to reveal both the quantitative (Khlyzova \& Latkin, 2015) and qualitative aspect of the issue.

In the rhythmicity of dusk-flying insects, including mosquitoes, relation to the illuminance is the most clearly manifested (Nayar \& Sauerman, 1971; Chernyshev, 1981). According to Monchadskiy (1950, 1958), the periodic changes in the light over 24-h is determined by development and the main patterns of the 24-h rhythm, i.e. its qualitative aspect, and the changes in the temperature within the optimum and transitional zones influence only on the qualitative aspect of the 24-h rhythm. According to Monchadskiy (1950) and Pestryakova et al. (1976), the optimum illuminance equals 10-500 lux. In the forest-steppe zone of Tyumen Oblast, the study of the 24-h rhythm was conducted at a low level of mosquito abundance, the highest activity of mosquitoes occurred in the period of dusk, which indicates that the illuminance is one of the main limiting factors. Under the forest canopy in June, mosquitoes struck throughout the twenty-four-hour period, however, during the daytime, their number significantly decreased. In July, when the number of mosquitoes was significantly low, their strikes during the daylight hours either were not observed or the strikes were made by single individuals. Over the seasons of the study in the southern taiga and small-leaved aspenbirch forests, the number of mosquitoes was high, and the active strikes of females on humans and animals was observed at illuminance from 0 to 3700 lux, which is 7 times higher than the border value mentioned in the literature. Some researchers mention the influence of the moon's cycle on the activity of mosquitoes, the literature describes the fact that one species were more active over the new moon phase, and the other preferred full moon (Davies, 1975; Charlwood et al., 1986; Guimarães et al., 2000).

According to the literature data, in all landscape-climatic zones of Western Siberia, mosquitoes are active at the temperature $2-37^{\circ} \mathrm{C}$, with optimum of $7-5^{\circ} \mathrm{C}$ (Anufriyeva, 1971; Kukharchuk, 1981; Red'kina, 2008). The analysis of meteorological conditions developed during the study indicated that at relatively high temperatures in the night (not lower than $13^{\circ} \mathrm{C}$ ), the main factor which inhibits the intensity and the duration of the night activity at that time is mist with increased relative air humidity of up to $100 \%$, which coincides with the data of other researchers (Haufe, 1964). Low air humidity also negatively affects the activity of mosquitoes (Guimarães et al., 2000). We determined no negative impact of temperature $12.6-30.0{ }^{\circ} \mathrm{C}$ during the records.

One of the inhibiting factors for mosquitoes is strong wind. According to Kukharchuk (1981), their flight stopped at the wind speed of over $4 \mathrm{~m} / \mathrm{s}$. During our studies, we recorded strikes of single mosquitoes at the wind speed of $5 \mathrm{~m} / \mathrm{s}$.

Thus, apart from the main abiotic factors, the activity of mosquito females during their search of food is affected also by such biotic factors as their total number. The higher the number of mosquitoes, the harder it is for them to find food and receive the needed portion of blood. Hungry females were significantly active despite non-optimum conditions of the environment.

\section{Conclusions}

During the study of the 24-h activity of mosquitoes in southern Tyumen oblast, we recorded flight of 29 species of mosquitoes: in the subzone of the southern taiga - 25, in the subzone of small-leaved aspen-birch forests -20 , in the forest-steppe zone -24 species. The highest species diversity of striking mosquitoes occurred in all landscape-climatic zones of southern Tyumen oblast over the period of evening flight, i.e. at $23 \mathrm{~h}$. The minimum species diversity was observed in the daytime (11-17 h), when only the females of the commonest species struck actively. The pattern of 24-h activity of each species of mosquito depends on the total number of mosquitoes in the season of study and on the ecological peculiarities of the species, which is determined by the range of the main meteorological conditions optimum for its flight. For most species recorded during the study, the optimum temperature range for active flight and strikes was $15-20^{\circ} \mathrm{C}$.

This report was prepared thanks to financial support from FANO Russia within the framework of the topic FSR No 0408-2014-0025 “Current state of biodiversity of Southwest Siberia as a reflection of anthropogenic transformation of the landscape".

\section{References}

Anufriyeva, V. N. (1971). Biologiya i ekologiya krovososushchikh komarov (Diptera, Culicidae) v yugo-vostochnoy chasti Zaysanskoy kotloviny, ikh vozmozhnoye epidemiologicheskoye znacheniye i predposylki k meram bor'by [Biology and ecology of blood-sucking mosquitoes (Diptera, Culicidae) in the southeastern part of the Zaisan hollow, their possible epidemiological significance and prerequisites for protective measures]. Moscow (in Russian).

Charlwood, J. D. (1996). Biological variation in Anopheles darlingi root. Memórias do Instituto Oswaldo Cruz, 91(4), 391-399.

Charlwood, J. D., Paru, R., Dagoro, H., \& Lagog, M. (1986). Influence of Moonlight and gonotrophic age on biting activity of Anopheles farauti (Diptera: Culicidae) from Papua New Guinea. Journal of Medical Entomology, 23(2), 132-135.

Chernyshev, V. B. (1981). Vzaimosvyaz' sutochnykh ritmov aktivnostey nasekomogo [Interrelation of diurnal rhythms of insect activities]. Voprosy Obshchey 
Entomologii. Trudy Vsesoyuznogo Entomologicheskogo Obshchestva. Nauka, Leningrad, 63, 159-162 (in Russian).

Davies, J. B. (1975). Moonlight and the biting activity of Culex (Melanoconion) portesi Senevet \& Abonnenc and C. (M.) taeniopus D. \& K. (Diptera, Culicidae) in Trinidad forests. Bulletin of Entomological Research, 65(1), 81-96.

Forattini, O. P., \& de Castro Gomes, A. (1988). Biting activity of Aedes scapularis (Rondani) and Haemagogus mosquitoes in Southern Brazil (Diptera: Culicidae). Revista de Saúde Pública, 22(2), 84-93.

Gornostayeva, R. M. (2009). Novyy spisok komarov (Diptera: Culicidae) Rossii [A new list of mosquitoes (Diptera: Culicidae) in Russia]. Meditsinskaya Parazitologiya i Parazitarnyye Bolezni, 1, 60-62 (in Russian).

Gornostayeva, R. M., \& Danilov, A. V. (1999). Komary Moskvy i Moskovskoy oblasti [Mosquitoes of Moscow and the Moscow region]. KMK Scientific Press, Moscow (in Russian).

Guimarães, A. E., Gentile, C., Lopes, C. M., \& de Mello, R. P. (2000). Ecology of mosquitoes (Diptera: Culicidae) in Areas of Serra do Mar State Park, State of São Paulo, Brazil. III - Daily biting rhythms and lunar cycle influence. Memórias do Instituto Oswaldo Cruz, 95(6), 753-760.

Guimarães, A. E., de Mello, R. P., Lopes, C. M., \& Gentile, C. (2002). Ecology of mosquitoes (Diptera: Culicidae) in Areas of Serra do Mar State Park, State of São Paulo, Brazil. I - Monthly frequency and climatic factors. Memórias do Instituto Oswaldo Cruz, 95(1), 1-16.

Haufe, W. O. (1964). Quantitative measurements of activity of Aedes aegypti (L.) (Culicidae: Diptera) in response to changes in the hygrothermal environment. International Journal of Biometeorology, 7(3), 245-264.

Khlyzova, T. A., \& Latkin, S. V. (2015). Sutochnyy ritm aktivnosti krovososushchikh komarov (Diptera, Culicidae) v usloviyakh yuga Tyumenskoy oblasti [Diurnal rhythm of activity of blood-sucking mosquitoes (Diptera, Culicidae) in conditions of the south of the Tyumen region]. Vestnik Tyumenskogo Gosudarstvennogo Universiteta. Ekologiya i Prirodopol'zovaniye, 1(3), 137-143 (in Russian).

Khlyzova, T. A., \& Pavlova, R. P. (2006). Sutochnyy ritm aktivnosti krovososushchikh komarov (Diptera, Culicidae) v usloviyakh yuzhnoy taygi [Diurnal rhythm of activity of blood-sucking mosquitoes (Diptera, Culicidae) in conditions of the southern taiga]. Trudy Vserossiyskogo NauchnoIssledovatel'skogo Instituta Veterinarnoy Entomologii i Arakhnologii, 201-212 (in Russian).

Kim, H., Shin, E., Chang, K. S., Roh, J. Y., \& Lee, W. G. (2016). Ecological study on Aedes albopictus (Diptera: Culicidae) in Korea. XXV International Congress of Entomology. Orlando, Florida, USA. September 25-30. Poster D3908.

Kukharchuk, L. P. (1980). Krovososushchiye komary (Diptera, Culicidae) Sibiri. Sistematika [Blood-sucking mosquitoes (Diptera, Culicidae) of Siberia. Systematics]. Nauka, Novosibirsk (in Russian).

Kukharchuk, L. P. (1981). Ekologiya krovososushchikh komarov (Diptera, Culicidae) Sibiri [Ecology of blood-sucking mosquitoes (Diptera, Culicidae) of Siberia]. Nauka, Novosibirsk (in Russian).
Monchadskiy, A. S. (1950). Napadeniye komarov na cheloveka v prirodnykh usloviyakh Subarktiki i faktory, yego reguliruyushchiye [The attack of mosquitoes on humans in natural conditions of the Subarctic and the factors that regulate it]. Parazitologicheskiy Sbornik ZIN AN SSSR, 12, 123166 (in Russian).

Monchadskiy, A. S. (1958). O klassifikatsii faktorov okruzhayushchey sredy [On the classification of environmental factors]. Zoologicheskiy Zhurnal, 37(5), 680-692 (in Russian).

Montarsi, F., Mazzon, L, Cazzin, S., Ciocchetta, S., \& Capelli, G. (2015). Seasonal and daily activity patterns of mosquito (Diptera: Culicidae) vectors of pathogens in Northeastem Italy. Joumal of Medical Entomology, 52(1), 56-62.

Nayar, J. K., \& Sauerman, D. M., (1971). The effect of light regimes on the circadian rhythm of flight activity in the mosquito Aedes taeniorhynchus. Journal of Experimental Biology, 54, 745-756.

Pesenko, Y. A. (1982). Printsipy i metody kolichestvennogo analiza v faunisticheskikh issledovaniyakh [Principles and methods of quantitative analysis in faunistic studies]. Nauka, Moscow (in Russian).

Pestryakova, T. S., Luzhkova, A. G., \& Fominykh, V. G. (1976). Komary i slepni Tomskoy oblasti (Biologiya i mery zashchity) [Mosquitoes and hives of the Tomsk region (Biology and protection measures)]. Izdatel'stvo TGU, Tomsk (in Russian).

Petrozhitskaya, L. V., Rod'kina, V. I., \& Mirzayeva, A. G. (2002). Ob unifikatsii dannykh raznykh sposobov kolichestvennykh uchetov imago krovososushchikh (Diptera) nasekomykh [On the unification of data of different methods of quantitative counts of imago bloodsucking (Diptera) insects]. 12 S'yezd Russkogo Entomologicheskogo Obshchestva. Sankt-Peterburg, 19-24 avgusta 2002 g.: Tezisy dokladov. Sankt-Peterburg. Pp. 280-281 (in Russian).

Polyakova, P. Y., \& Patrusheva, V. D. (1974). Fauna i ekologiya komarov (Diptera, Culicidae) Yuzhnogo Yamala [Fauna and ecology of mosquitoes (Diptera, Culicidae) of Southern Yamal]. Fauna i ekologiya nasekomykh Sibiri. Nauka, Novosibirsk. Pp. 90-100 (in Russian).

Rasnitsyn, S. P., \& Kosovskikh, V. P. (1979). Usovershenstvovannyy metod ucheta obiliya komarov sachkom vokrug cheloveka i sravneniye yego s uchetom temnym kolokolom [An improved method of accounting for the abundance of mosquitoes around a human with a net and comparing it to counts using a dark bell]. Meditsinskaya Parazitologiya i Parazitarnyye Bolezni, 1, 18-24 (in Russian).

Red'kina, N. V. (2008). Krovososushchiye komary (Diptera, Culicidae) antropogennykh territorii yugo-vostoka Zapadnoy Sibiri na primere gorodov Tomska i Strezhevogo [Blood-sucking mosquitoes (Diptera, Culicidae) of anthropogenic territories of the southeast of Western Siberia on the example of the cities of Tomsk and Strezhevoy]. Tomsk (in Russian).

Voorham, J. (2002). Intra-population plasticity of Anopheles darlingi's (Diptera, Culicidae) biting activity patterns in the state of Amapá, Brazil. Revista de Saúde Pública, 36(1), 75-80. 